\title{
A teologia do laicato no Vaticano II: revisitação a partir do pontificado do Papa Francisco
}

\author{
Theology of the laity in Vatican II: \\ revisiting from the pontificate of Pope Francis
}

Elias Wolff

\section{Resumo}

A compreensão do lugar e do papel das leigas e dos leigos na Igreja em nossos tempos só é possível através de uma revisitação do concílio Vaticano II. Esse concílio dedica especial atenção a essa questão no horizonte de uma eclesiologia desenvolvida na perspectiva do Povo de Deus, de comunhão e participação. É fundamental compreender a Igreja como uma comunidade formada por todos os cristãos batizados, numa comum responsabilidade de sujeitos e ministérios. E o fazemos revisitando o Vaticano II, dando nova explicitação dos elementos chaves da sua teologia do laicato. Com um pé na teologia dos Padres da Igreja e sua eclesiologia essencialmente comunitária, trazemos de volta aqui o magistério conciliar sobre o leigo, destacando o significado teológico desse termo, a especificidade da ação do leigo no mundo, a pastoral do leigo e suas dimensões, o leigo nas estruturas de governo da Igreja. A retomada do ensino do Vaticano II sobre o laicato é o que dá plausibilidade à realização do projeto eclesial do pontificado do papa Francisco e do ano do laicato na Igreja do Brasil.

Palavras-chave: Igreja. Vaticano II. Laicato. Ministérios. Povo de Deus.

\section{Abstract}

The understanding of place and role of a layperson in the Church in our times is only possible through a revisit of the Second Vatican Council. 
This council dedicates particular attention to this issue through the scope of an ecclesiology developed in the perspective of the People of God, of communion and participation. It is fundamental to understand the Church as a community formed by all baptized Christians, in a common responsibility of subjects and ministries. And we do it by revisiting the Vatican II, giving a new explanation for the key elements of its theology of the laity. With a foot in the theology of the Fathers of the Church and its essentially communitarian ecclesiology, we bring back here the conciliar magisterium on the layman, highlighting the theological meaning of this term, the specificity of lay action in the world, the pastoral of the layperson and their dimensions, the layman in the structures of government of the Church. The resumption of teaching of Vatican II on the laity is what gives plausibility to the realization of the ecclesial project of the pontificate of pope Francis and the year of the laity in the Church of Brazil.

Keywords: Church. Vatican II. Laicate. Ministries. People of God.

\section{Introdução}

Há pouco mais de cinquenta anos da realização do Concílio Vaticano II e em tempos do pontificado do papa Francisco, observamos que apesar de todos os esforços o Vaticano II não foi ainda assumido de forma convincente em sua eclesiologia, sua espiritualidade, sua proposta de missão no mundo. Tal é o que constatou o papa Francisco em vários de seus pronunciamentos. E isso afeta no modo como se compreende a presença e atuação do conjunto dos cristãos batizados na Igreja. Nem todos fazem tudo, é claro. Mas em algumas situações a divisão de funções expressa divisão da comunidade de fé, alguns tendo um status eclesial mais relevante que outros. Daqui as posturas de clericalismo, carreirismo, individualismo e autorreferencialidade, dentre outras "tentações dos agentes de pastoral” (EG 76-77), ${ }^{1}$ que tornam difícil, se não impossível, pensar numa Igreja de comunhão e participação em igual dignidade batismal de todos os seus membros.

\footnotetext{
${ }^{1}$ FRANCISCO. Evangelii Gaudium. São Paulo: Paulus/Loyola, 2013. Doravante citado pela sigla EG.
} 
Com isso, uma das consciências mais fragilizadas na Igreja é a da laicidade. São as leigas e os leigos que mais sofrem nas relações eivadas de interesses, gostos e tendências clericais nada evangélicos, o que torna a missão carente de enraizamento teológico e espiritual. O binômio "cleroleigos" ainda não foi substituído por "comunidade-ministérios", como propõem alguns. Tendências eclesiológicas em oposição dificultam para o exercício da corresponsabilidade na missão entre o clero e o laicato e é necessário responder ainda à questão se o laicato é, na Igreja, "ovelha ou protagonista". ${ }^{2}$

Nesse contexto, urge retomar o concílio Vaticano II em seu conjunto para compreender o lugar e a missão das leigas e dos leigos na Igreja e no mundo. E tal é o que faz o papa Francisco, em três principais horizontes: eclesiológico, entendendo a Igreja como Povo de Deus; sacramental, a partir do Batismo comum; e missiológico, propondo uma conversão pastoral em perspectiva missionária. Em sintonia com o Vaticano II o papa Francisco afirma que a responsabilidade laical nasce do Batismo que insere leigas e os leigos no coração da Igreja e os leva a assumirem a sua missão no mundo (EG 102). São "força e esperança da Igreja no mundo". 3 Mas são muitos os desafios para colocar em prática esse ensinamento neste tempo no qual muitos católicos estão espiritual e teologicamente distanciados do magistério conciliar e a consciência de uma Igreja laical está se fragilizando por perder a capacidade de escuta da voz que a orienta e forma o chão no qual ela se enraíza.

Motivados pelas iniciativas do atual pontificado, retomamos o ensino dos Padres entendendo que neles encontramos a compreensão de Igrejacomunidade, que é a chave para o desenvolvimento da eclesiologia do povo de Deus no Vaticano II, onde se enraíza o ministério laical. Esperamos que tal intento contribua especialmente para a Igreja no Brasil que celebra agora o Ano do Laicato, refletindo sobre "Cristãos leigos e leigas na Igreja e na sociedade". ${ }^{4}$

\footnotetext{
${ }^{2}$ BLANK, R. Ovelha ou Protagonista? A Igreja e a nova autonomia do laicato no século 21. São Paulo: Paulus, 2006.

${ }^{3}$ KUZMA, C. Leigos e Leigas. Força e esperança da Igreja no mundo. São Paulo: Paulus, 2009.

${ }^{4}$ CNBB. Cristãos Leigos e Leigas na Igreja e na Sociedade - Sal da terra e luz do mundo. Documento de Estudos n. 105. Brasília: Edições da CNBB, 2018.
} 


\section{A laicidade da Igreja no período patrístico}

O termo grego laikos tem sua raiz etimológica no substantivo laos, povo. O sufixo -ikos dá ao adjetivo um significado próprio, designando uma categoria oposta a outra no meio do povo. Em papiros antigos, "laikos" indica a massa dos habitantes, distinta dos que administram. Na Bíblia, o termo é inexistente na versão dos Setenta, mas encontrado nas versões de Áquila, Símaco (o Ebionita) e Teodócio (século II d.C.). No Novo Testamento, laikos é ausente. ${ }^{5}$

Nas comunidades cristãs dos primeiros séculos o adjetivo laikos já está presente, como se verifica na carta de Clemente Romano aos Coríntios, $(40,6)$, de Clemente de Alexandria (Stromata 3, 12, 90, 1; 3; Pedagogo 3, 10 83, 2), em Orígenes (Homilia 11,3), como também na carta de Clemente a Tiago nas Pseudo-Clementinas 5,5. ${ }^{6} \mathrm{O}$ uso desse termo tem a intenção de designar o fiel, distinguindo-o do diácono ou presbítero oficiante do culto. Mas é importante observar que o seu significado original é neutro do ponto de vista religioso; simplesmente especifica uma categoria no âmbito do povo, sem incluir a noção de "sagrado". Ele não quer contrapor "povo" e "hierarquia". Assim, laikos significa, de um lado, a pertença a um povo; e, de outro lado, a pertença a uma categoria específica no meio desse povo. ${ }^{7}$

Com o tempo, os batizados que não possuem um ministério hierárquico se compreendem sempre mais pelo distanciamento da vida clerical, e aqui vem o tom de negatividade do conceito "leigo". Clemente, em sua Carta aos Coríntios, afirma: "O leigo é regido pelas regras fixadas para os leigos" $(40,6)$; Inácio de Antioquia mostra em suas Cartas que a comunidade está articulada ao redor do bispo (Aos filadelfos, 4; Aos Esmirnenses, 8, etc.); Justino na $I$ Apologia, 67, diz que o povo responde ao presidente da assembleia na celebração eucarística; Cipriano mostra a oposição entre o clero e a plebs (Epist. 45,2); a Tradição Apostólica de Hipólito Romano estabelece leis particulares para os leigos; Clemente Alexandrino e Orígenes usam o termo leigo como distinto ou mesmo separado dos sacerdotes; e Tertuliano, em Do Batismo afirma que também os leigos podem administrar o Batismo, pois "aquilo que todos recebem no mesmo grau todos podem dar no mesmo grau”. E em Prescrição aos Hereges, diz que entre os hereges montanistas "os ofícios sacerdotais são

\footnotetext{
${ }^{5}$ Cf. FORTE, B. A Missão dos Leigos. São Paulo: Paulinas, 1987, p. 21.

${ }^{6}$ Cf. FORTE, B. A Missão dos Leigos, p. 21.

${ }^{7}$ Cf. FORTE, B. A Missão dos Leigos, p. 22.
} 
impostos também aos leigos". ${ }^{8}$ Disso decorre que o significado de leigo vai assumindo também um sentido pejorativo como alguém não consagrado ao serviço do ministério hierárquico, alguém cujas condições de vida o enxertam no mundo - idéia que reflete o influxo do pensamento grego.

Mas é importante ressaltar que no período patrístico os leigos não se identificam apenas negativamente, como o que não pertence ao clero. Eles possuem carismas e ministérios a serviço da comunidade, como Justino, filósofo e mártir, que é leigo pregador do Evangelho. Além do clero, cada cristão tem seu carisma: é didascalos, mártir, confessor, asceta, etc., numa variedade carismática e ministerial do laicato cristão. "Todos são sujeitos da luminosa manifestação dos carismas, doados de maneira extremamente mais modesta a uma infinidade de outros leigos". 9 Assim, a distinção entre grupos de cristãos não dividia a comunidade em polos contrastantes. A comunidade cristã possuía uma articulação interna na qual se afirma a organização hierárquica sem tirar o vigor da variedade de ministérios e carismas. Nelas prevalecia o princípio da koinonia, numa articulação equilibrada entre clero e leigos. Isso mostra que os pólos de tensão na comunidade não eram $a d$ intra, entre clero e leigo, mas ad extra, entre Igreja e mundo. Os cristãos eram conscientes da missão de anunciar ao mundo a salvação em e por Jesus Cristo. Daqui surgiram diferenciados ministérios e estruturas comunitárias, que com o tempo ganham fundamentação teológica.

\section{Os leigos no Vaticano II}

\subsection{Significado teológico do termo}

Na Idade Média, o termo "leigo" foi utilizado para designar o povo e tem forte conotação pejorativa ao indicar quem era iletrado que não tinha acesso à Bíblia e nem sabia o latim. "Leigo" é, então, alguém que adota a atitude do silêncio e da escuta do clero falante, pois este tem a inteligentia da fé, enquanto o leigo é o inculto, o analfabeto, o que deve ser instruído na religião pelo clero. Assim, o clero tem a "posse" da missão da Igreja e se distancia sempre mais do povo no modo de ser e de agir. Na Idade Moderna, o conceito "leigo" foi utilizado por diferentes áreas humanas, mas em geral com sentido negativo, de

\footnotetext{
${ }^{8}$ Cf. FORTE, B. A Missão dos Leigos, p. 21.

${ }^{9}$ LANNE, E. “Le Laicat dans l'Eglise Ancienne”, Apud FORTE, B. A Missão dos Leigos, p. 29.
} 
quem não é conhecedor de algo, ou não é apto para algo, sobretudo indicando o que não pode ser feito na Igreja por quem não possui o ministério ordenado.

Acentua-se a distância da eclesiologia bíblica e patrística do Povo de Deus, comunidade, na Bíblia presente sobretudo em Lucas e em Paulo. A raiz é o Primeiro Testamento, onde Povo de Deus é a mais comum das designações de Israel. O laos - povo - tem em cada fiel um laikos - leigo. O sentido primeiro de leigo era sinônimo de fiel. Isso foi abandonado na história da Igreja pela ênfase clerical de sua organização.

É isso que o papa Francisco, retomando o Vaticano II, busca recuperar. Diz o Vaticano II:

Pelo nome de leigos aqui são compreendidos todos os cristãos, exceto os membros da ordem sacra e do estado religioso aprovado na Igreja. Estes fiéis pelo batismo foram incorporados a Cristo, constituídos como Povo de Deus e a seu modo feitos partícipes do múnus sacerdotal, profético e régio de Cristo, tendo parte ativa na missão de todo o povo cristão na Igreja e no mundo (LG 31). ${ }^{10}$

O Concílio oferece aqui uma compreensão genérica de leigo, mas que "acaba de vez com o conceito meramente negativo e passivo, rejeitando decididamente o clericalismo e colocando o leigo ativamente na Igreja, de modo a participar dos ministérios de santificar, de ensinar, de reger, ou da missão total da Igreja" ${ }^{11}$ Em comunhão conciliar o papa Francisco entende que "existe uma forma de liberdade laical através de experiências de povo... Aqui se vê uma maior autonomia... A proposta dos grupos bíblicos, das comunidades eclesiais de base e dos Conselhos pastorais se colocam na linha de superação do clericalismo e de um crescimento da responsabilidade laical". ${ }^{12}$

É no interior da categoria de Povo de Deus que o Concilio e o papa Francisco compreendem a condição laical dos batizados. O horizonte eclesiológico é global, entendendo a Igreja como a totalidade das pessoas batizadas na fé em Cristo. Antes de alguém ser considerado na Igreja como "leigo" ou "diácono"

\footnotetext{
${ }^{10}$ CONCÍLIO VATICANO II. "Lumen Gentium”. In: DOCUMENTOS DO CONCÍLIO VATICANO II. São Paulo: Paulus, 2007, pp. 101-192. Doravante citado pela sigla EG.

${ }^{11}$ KLOPPENBURG, B. A Eclesiologia do Vaticano II. Petrópolis: Vozes, 1971, p. 241.

${ }^{12}$ FRANCISCO. "Textos do Papa Francisco na sua viagem apostólica ao Brasil, por ocasião da XXVIII Jornada Mundial da Juventude (22 a 28 de julho de 2013) - Encontro com os dirigentes do CELAM". Disponível em: <www.diocesedejales.org.br/home/discursos-e-homilias-do-papa-francisco-na-jmj-rio-2013/>. Acesso em 22 de janeiro de 2018.
} 
ou "presbítero" ou "bispo" ou "papa", ele é cristão. Tal é o sentido do termo laicus no cap. IV da Lumen Gentium, o qual deve ser lido em sintonia com o cap. I que fala do mistério da Igreja, o cap. II, que descreve o Povo de Deus em geral, e o cap. V, que trata da vocação universal à santidade. Nesse conjunto, o Concílio apresenta o conceito de leigo com a maior dignidade possível, a partir da sua positividade, e não a partir da negação da pertença ao estado clerical. Retomando a patrística, o significado de leigo é afirmado, primeiramente, como sinônimo de fiel, cristão, membro do Povo de Deus; e, em segundo lugar, faz-se a distinção de quem é membro da ordem sacra e do estado religioso. ${ }^{13}$ As leigas e os leigos são "sujeitos" tanto na Igreja quanto no mundo. ${ }^{14} \mathrm{E}$ para apresentar o leigo como alguém que não pertence à hierarquia, é preciso evitar a conotação de "profano", mostrando que a inserção no mundo constitui uma vocação eclesial, e a ação terrena é uma missão essencial para a evangelização do mundo. O desafio prático precisa responder às perguntas do papa Francisco: "Na prática, fazemos os fiéis leigos participantes da Missão?... Nós, Pastores Bispos e Presbíteros, temos consciência e conviç̧ão da missão dos fiéis e lhes damos a liberdade para irem discernindo, de acordo com o seu caminho de discípulos, a missão que o Senhor lhes confia?". ${ }^{15}$

O leigo é, portanto, primeiramente um cristão comprometido com sua consciência eclesial de pertença ao Povo de Deus. E a Igreja em sua totalidade é uma comunidade de vida e missão. A vida e a missão da Igreja são oriundas do próprio Cristo, que a faz seu Corpo Místico. Portanto, não se compreende o leigo negativamente, como apenas alguém que não possui o grau hierárquico. Como cristão membro do Povo de Deus, todos os batizados possuem direitos e deveres comuns a todos os fiéis, cada um é vocacionado por Deus para exercer de um modo próprio a missão da Igreja no mundo.

\subsection{A comum dignidade cristã na diversidade da missão}

Com a categoria eclesiológica "Povo de Deus" afirma-se uma fundamental e comum dignidade de todos os cristãos, de modo que "tudo

\footnotetext{
${ }^{13}$ ROXO, R. M. O Concílio. Petrópolis: Vozes, 1967, p. 213.

${ }^{14}$ PASSOS, J. D. Sujeito no Mundo e na Igreja. Reflexões sobre o laicato a partir do concílio Vaticano II. São Paulo: Paulinas, 2014.

${ }^{15}$ FRANCISCO. "Textos do Papa Francisco na sua viagem apostólica ao Brasil, por ocasião da XXVIII Jornada Mundial da Juventude (22 a 28 de julho de 2013) - Encontro com os dirigentes do CELAM". Acesso em 22 de janeiro de 2018.
} 
o que foi dito acerca do Povo de Deus se dirige de igual modo aos leigos, religiosos e clérigos" (LG 30). Assim, antes de pensar nas funções dentro da Igreja, faz-se necessário compreendê-la como corpo total. Aqui não há distinção quanto à dignidade de cada fiel. Numa eclesiologia total, é "comum a dignidade dos membros pela regeneração em Cristo. Comum a graça dos filhos. Comum a vocação à perfeição. Uma a salvação, uma a esperança, indivisa a caridade" (LG 40). Essa igualdade na dignidade é também quanto à responsabilidade na missão: "Sabemos que há uma única missão da Igreja de Deus, e cada cristão batizado tem um papel vital nesta missão". ${ }^{16}$ Assim, leigas e os leigos contribuem "para o incremento da Igreja e sua própria santificação" (LG 33). Pois

Um é o Povo eleito de Deus ... comum a dignidade dos membros pela regeneração em Cristo. Comum a graça de filhos. Comum a vocação à perfeição... reina, contudo, entre todos verdadeira igualdade quanto à dignidade e ação comum a todos os fiéis na edificação do Corpo de Cristo (LG 32).

Desse modo, hierarquia, religiosos e leigos/as não constituem graus diversos quanto à dignidade que os incorpora na Igreja, de modo que o leigo se caracteriza pelo fato cristão comum à hierarquia: "é evidente que todos os fiéis cristãos, de qualquer estado ou ordem, são chamados à plenitude da vida cristã e à perfeição da caridade" (LG 30). A comum dignidade cristã se dá pela ação do mesmo Espírito que atua no íntimo de cada fiel e desafia a "descobrir e transmitir a 'mística' de viver juntos, misturar-nos, encontrar-nos, dar o braço, apoiar-nos ... numa verdadeira experiência de fraternidade” (EG 87).

Tal não significa, porém, afirmar igualdade no estado de vida e de competências no interior da Igreja. O Espírito que em todos atua é o fundamento também da diversidade. A hierarquia recebe o sacramento da Ordem para ser tal; e os leigos e as leigas atuam na Igreja e no mundo através de um outro modo próprio de participação do tríplice múnus de Cristo (LG 31). O Espírito lhes concede carismas, dons e graças especiais (LG 12). Consequentemente, a realidade cristã essencial é comum a todo batizado, mas em sua vivência, manutenção e transmissão há uma saudável diversidade que distingue laicato

16 FRANCISCO. "Encontro com os líderes do apostolado leigo" (República da Coreia, VI Jornada da Juventude Asiática, República da Coreia, 16/08/2014). Disponível em: $<$ http://w2.vatican.va/content/francesco/pt/speeches/2014/august/documents/papa-francesco_20140816_corea-leader-apostolato-laico.html>. Acesso em 28 de janeiro de 2018. 
e clero. Assim, o ser cristão realiza-se na diversidade de membros e ofícios na Igreja. O que é comum realiza-se existencialmente e concretamente de modo diverso. A razão disso é o modo como se vive existencialmente a relação com Cristo: pelo sacramento da Ordem, o ministro ordenado relaciona-se com Cristo Cabeça - Pastor da Igreja (PO), ${ }^{17}$ de onde deriva a responsabilidade de coordenação da comunidade de fé. O leigo vive essa relação pelo sacramento do Batismo, pelo qual ele "tem a Cristo como irmão" (LG 32) e pertence ao corpo eclesial. Para alguns, essa compreensão fortalece a hierarquia na Igreja, em detrimento da comunidade. Mas não é o que se propõe. A hierarquia e os batizados configuram um mesmo ser eclesial, com diversidades legítimas nos modos de ser e agir na Igreja e no mundo. Pergunta o papa Francisco: "Porque o diácono, o sacerdote, é mais importante que o leigo? Não! É este o erro! É um bom leigo? Que continue e cresça assim". Afinal, "cada um tem sua importância nessa harmonia. A Igreja é a harmonia da diversidade. O corpo de Cristo é esta harmonia da diversidade, e é o Espírito Santo que faz a harmonia: Ele é o mais importante de todos". ${ }^{18}$

\subsection{A especificidade da missão laical}

No conjunto da missão da Igreja, o concílio explicita a ação específica do fiel cristão "leigo". Não se trata de afirmar que ele faz aquilo que a hierarquia não consegue ou não pode fazer. Trata-se, antes, de entender que algo the é próprio na Igreja. A especificidade de sua missão é o mundo no qual vive:

a índole secular caracteriza especialmente os leigos... É específico dos leigos, por sua própria vocação, procurar o Reino de Deus exercendo funções temporais e ordenando-as segundo Deus. Vivem no século, isto é, em todos e em cada um dos ofícios e trabalhos do mundo. Vivem nas condições cotidianas da vida familiar e social, o contexto de sua existência. Lá são chamados por Deus para que, exercendo seu próprio oficio, guiados pelo espírito evangélico, contribuam de dentro, a modo de fermento, para a santificação do mundo. E assim manifestam Cristo aos

\footnotetext{
${ }^{17}$ CONCÍLIO VATICANO II. "Presbiterorum Ordinis". In: DOCUMENTOS DO CONCÍLIO VATICANO II. São Paulo: Paulus, 2007, pp. 491-536. Doravante citado pela sigla PO.

${ }^{18}$ FRANCISCO. "Discurso do papa Francisco aos membros da associação 'corallo' que reúne as emissoras televisivas católicas italianas" (22/03/2014). Disponível em: <https://w2.vatican. $\mathrm{va} /$ content/francesco/pt/speeches/2014/march/documents/papa-francesco_20140322_ associazione-corallo.html $>$. Acesso em 15 de janeiro de 2018.
} 
outros, especialmente pelo testemunho de sua vida resplandecente em fé, esperança e caridade. A eles, portanto, cabe de maneira especial iluminar e ordenar de tal modo todas as coisas temporais, às quais estão intimamente unidos, que elas continuamente se façam e cresçam segundo Cristo, para louvor do Criador e Redentor (LG 31).

Os elementos centrais dessa afirmação são:

1) Índole secular do ministério laical: três afirmações fundamentais do Concílio: a) "a vivência do evangelho para os leigos não só não se opõe ao exercício das tarefas temporais, mas exige total fidelidade a elas (GS 43); ${ }^{19}$ b) o modo de "fermento", isto é, agindo com engajamento sério no mundo; c) a santificação do mundo, a sua conversão na reforma constante "de todas as realidades que constituem a ordem temporal, como sejam os bens da vida e da família, a cultura, a economia, artes e profissões, instituições políticas, relações internacionais" (AA 7). ${ }^{20}$ Confirma o papa Francisco: "É necessário que os leigos católicos não permaneçam indiferentes à vida pública nem fechados nos seus templos, nem sequer que esperem as diretrizes e as recomendações eclesiais para lutar a favor da justiça, de formas de vida mais humanas para todos". ${ }^{21}$

Desse modo, a vida cristã leiga consagra o mundo pela "renovação da ordem temporal como sua função própria" (AA 7. Também: EG 201). Para essa consagração, é fundamental: 1) que os leigos operem "de maneira direta e definida, guiados pela luz do evangelho e pela mente da Igreja e levados pela caridade cristã" (AA 7); 2) "Cooperem como cidadãos com os cidadãos, com sua competência específica e responsabilidade própria” (AA 7); 3) respeitando as leis próprias da ordem temporal, elevando-a aos princípios mais altos da vida cristã e fazendo que ela se adapte às condições diversas de lugares,

${ }^{19}$ CONCÍLIO VATICANO II. "Gaudium et Spes”. In: DOCUMENTOS DO CONCÍLIO VATICANO II. São Paulo: Paulus, 2007, pp. 539-558. Doravante citado pela sigla GS.

${ }^{20}$ ROXO, R. M. O Concilio, pp. 217-218; CONCÍLIO VATICANO II. “Apostolicam Actuositatem". In: DOCUMENTOS DO CONCÍLIO VATICANO II. São Paulo: Paulus, 2007, pp. 369-408. Doravante citado pela sigla AA.

${ }^{21}$ FRANCISCO. "Mensagem de vídeo do papa Francisco aos participantes no encontro de políticos católicos organizado pelo Conselho Episcopal Latino-americano e pela Pontifícia Comissão para a América Aatina (cal)" (Bogotá 1 - 3/12/2017). Disponível em: <http:// w2.vatican.va/content/francesco/pt/messages/pont-messages/2017/documents/papa-francesco_20171201_videomessaggio-cattolici-inpolitica.html $>$. Acesso em 10 de dezembro de 2017. 
tempos e povos; 4) a obra mais importante da missão laical é a ação em todos os setores temporais, seja pela proximidade da ação social com a caridade cristã, seja porque sinaliza para hoje a voz de Deus pelo anseio universal por uma ordem social mais justa e mais humana. ${ }^{22}$

2) Vocação na Igreja: a vocação das pessoas cristãs leigas é uma vocação eclesial (LG 7.12), que as faz fermento no mundo e tem sua especificidade no viver integralmente o mistério cristão exercendo as funções temporais. A ação laical como vocação implica um chamado especial de Deus para um trabalho específico: "procurar o reino de Deus exercendo funções temporais e ordenando-as segundo Deus". Dentre o apostolado de santificação, evangelização e animação, este último é destacado como o específico da ação leiga, a vocação própria da pessoa batizada. Deste modo é que as leigas e os leigos contribuem "para o incremento da Igreja e sua perene santificação" (LG 33), difundindo o reino de Cristo por toda a terra, fazendo de todo ser humano participante da redenção a fim de, por eles, ordenar o mundo inteiro a Cristo e animar a ordem temporal com o espírito evangélico. E para isso é preciso ousadia, coragem, a parresia da fé. Pois "muitas vezes nós vemos que se prefere uma pastoral de manutenção e não deixar que o Reino cresça. 'Mas, vamos permanecer aquilo que somos, pequeninos, ali, estamos seguros...' E o Reino não cresce. Para que o Reino cresça é preciso coragem: de lançar o grão, de misturar o fermento". ${ }^{23}$ Isso é apostolado laical em sentido próprio (AA 2).

3) Especificidade ou espaços e âmbitos da atuação do leigo: o leigo tem como espaço próprio de ação o mundo, e sua ação evangelizadora "adquire uma específica e peculiar eficácia, por ser realizada nas condições comuns do século". "Pois todas as suas obras, preces e iniciativas apostólicas, sua vida conjugal e familiar, seu trabalho cotidiano, seu descanso do corpo e da alma, se praticados no Espírito, e até mesmo os incômodos da vida pacientemente suportada tornam-se hóstias espirituais, agradáveis a Deus"(LG 34). A pastoral laical atinge "todas as realidades que constituem a ordem temporal, como sejam os bens da vida e da família, a cultura, a economia, artes e profissões,

${ }^{22}$ ROXO, R. M. O Concílio, pp. 221-222.

${ }^{23}$ FRANCISCO. "Homilia na missa na casa Santa Marta" (31/10/2017). Disponível em: $<$ http:// pt.radiovaticana.va/news/2017/10/31/papa_para_fazer_crescer_o_reino_de_deus_precisa-se_ coragem/1346200>. Acesso em 22 de dezembro de 2018 . 
instituições políticas, relações internacionais" (AA 7). Certamente há outras tantas atividades leigas, embora não comuns à sua condição de laicato. Algumas derivam do sacramento do matrimônio (educação dos filhos); outras de um carisma especial; ou são ligadas a um mandato específico da hierarquia (o Concílio fala aqui da Ação Católica). ${ }^{24}$ Fundamental é a consciência de que "precisamos de leigos bem formados, animados pela fé cristã, que "sujem suas mãos" e não tenham medo de errar, mas que prossigam adiante. Precisamos de leigos com visão do futuro e não fechados nas pequenezas da vida, mas experientes e com novas visões apostólicas". ${ }^{25}$

O mundo é o específico lugar da missão dos leigos, mas não lhe é exclusivo, pois nele está a Igreja como um todo e, portanto, também o clero testemunha e prega o Evangelho no mundo. Entende-se que a vocação eclesial do leigo (LG 7.12) o faz fermento no mundo e tem sua especificidade no viver integralmente o mistério cristão exercendo ali as funções próprias do seu jeito de ser Igreja. Porém, se "cada leigo individualmente deve ser perante o mundo uma testemunha da ressurreição e vida do Senhor Jesus e sinal do Deus vivo" (LG 38), tal responsabilidade é também da hierarquia. E cada um exercendo essa função no modo próprio do seu ministério, faz com que tanto o mundo quanto a Igreja possam sinalizar no mundo a realidade do Reino de Deus.

\section{O apostolado laical como mandato de Cristo}

O Concílio afirma que os hierarcas "não foram instituídos por Cristo com o fim de concentrarem em si apenas toda a missão salvífica da Igreja no mundo" (LG 30). E é dever da hierarquia "reconhecer nos fiéis suas atribuições e carismas, para que todos cooperem na obra comum" (LG 30. Também o n. 37). Também PO 9 lembra aos que possuem o ministério ordenado que "reconheçam com alegria e incentivem com entusiasmo os multiformes carismas dos leigos, dos modestos aos mais elevados".

Entende o Vaticano II que "o apostolado dos leigos é participação na própria missão salvífica da Igreja", e que se recebe "através do batismo e da confirmação" (LG 33), sendo os sacramentos, e sobretudo a Eucaristia, os que comunicam e alimentam "a caridade para com Deus e para com os homens,

${ }^{24}$ ROXO, R. M. O Concílio, p. 212.

${ }^{25}$ FRANCISCO. "Discurso aos participantes da assembleia do Pontifício Conselho para os Leigos" (jun. 2016). Disponível em: <http://blogs.opovo.com.br/ancoradouro/2016/06/17/precisamos-de-leigos-com-visao-do-futuro-diz-papa-francisco/>. Acesso em 15 de janeiro de 2018. 
que é a alma de todo o apostolado" (LG 33). O fundamental é perceber que "os leigos têm o dever e o direito do apostolado por sua própria união com Cristo ... recebem do próprio Senhor a delegação para o apostolado" (AA 3). Desse modo, o concílio define a questão se a ação dos leigos é o exercício de um mandato conferido pela hierarquia, como afirmavam alguns, ou se é o exercício do fato cristão próprio de todo fiel batizado, como afirmavam outros. Fica claro nas afirmações conclusivas que o leigo no apostolado que lhe é específico e próprio não age em virtude do mandato hierárquico, mas por delegação do próprio Cristo. Trata-se de um apostolado que compromete o indivíduo e a sua família inteira. Pelo sacramento do Matrimônio, por exemplo, os cônjuges cristãos "ajudam-se a santificar-se mutuamente na vida conjugal bem como na aceitação e educação dos filhos (como) um dom especial dentro do Povo de Deus" (LG 11). A família, "uma espécie de Igreja doméstica", onde os pais são para os filhos os primeiros arautos da fé cristã (LG 41).

A eficácia do apostolado depende da união com Cristo, "que é a luz do mundo, do qual procedemos, por quem vivemos e para quem tendemos" (LG 3). Tal foi o que o próprio Jesus falou: “Aquele que permanece em mim e eu nele, esse dá muito fruto, porque sem mim nada podeis fazer” (Jo 15,4-5).

\subsection{Dimensões do apostolado laical}

Pelo Batismo, as leigas e os leigos têm uma participação própria no tríplice múnus de Cristo.

a) Sacerdotal: A ação missionária do leigo no mundo tem como fundamento teologal a participação do leigo em Cristo sacerdote. Tratase de uma "união ontológica", ${ }^{26}$ pela qual o leigo é ungido pelo sacerdócio comum e régio, essencialmente (isto é, entitativamente) distinto do sacerdócio hierárquico e ministerial; mas verdadeiro sacerdócio sacramental que recebe do batismo", ${ }^{27}$ como atesta LG 10 e 34.

O Segundo Testamento afirma que Cristo é o único sumo e eterno Sacerdote (Hb 2,17; 4,14), único Pontífice e Mediador (1Tm 2,5). Do sacerdócio de Cristo participam, de maneira diversa e em graus diferentes, todos os batizados. Mas há uma distinção entre sacerdócio comum e sacerdócio ministerial. O Concílio afirma que "o sacerdócio comum dos fiéis

${ }^{26}$ ROXO, R. M. O Concílio, pp. 217-219.

${ }^{27}$ ROXO, R. M. O Concílio, pp. 217-219. 
e o sacerdócio ministerial ou hierárquico ordenam-se um ao outro, embora se diferenciem na essência e não apenas em grau. Pois ambos participam, cada qual a seu modo, do único sacerdócio de Cristo" (LG 10). Todo batizado é, pela unção do Espírito Santo, consagrado como casa espiritual e sacerdócio santo. Por essa razão o eterno Sacerdote une os leigos intimamente à sua vida e missão, concedendo-lhes parte de seu múnus sacerdotal (LG 34). Essa ação sacerdotal dos leigos se realiza:

- na oferta de sacrifícios espirituais em todas as obras do cristão (LG $10)$;

- na proclamação das grandezas d'Aquele que das trevas os chamou para a luz (LG 10);

- na perseverança em oração e no louvor comunitário a Deus (LG 10);

- na oferta de si mesmos como hóstia viva, santa e agradável a Deus (LG 10);

- na participação na oblação da Eucaristia (LG 10.11; SC 48);

- na recepção dos sacramentos (LG 11), na oração, na ação de graças, pelo testemunho de uma vida santa, pela abnegação e pela caridade ativa (LG 10);

É desse modo que os leigos, "agindo santamente como adoradores, consagram a Deus o próprio mundo" (LG 34).

Enfim, a dimensão sacerdotal do apostolado leigo está incluída no chamado universal de todo o Povo de Deus à santidade, como afirma o capítulo V da Lumen Gentium. A vontade de Deus é a santificação (LG 39.40). Tal é fruto da ação do Espírito Santo que a todos move interiormente para amar "a Deus com todo o coração, toda a alma, toda a mente e toda a sua força" e para que se amem mutuamente (LG 40). É nesse apostolado de santificação que se entende a afirmação de SC 79, de que alguns sacramentos, como o Batismo e o Matrimônio, podem ser administrados também por leigos, como hoje se observa no cotidiano das comunidades.

b) Profético: temos um único Profeta e Mestre, Cristo. Ele exerce seu múnus profético pela sua própria vida e pela vida dos seus discípulos. Do ministério profético de Cristo participam todos os batizados de maneira e em graus diferentes. Estão incluídos aqui tanto os que atualmente pertencem ao ministério ordenado, quanto os leigos "aos quais por isso constituiu 
testemunhas e ornou com o senso da fé e a graça da palavra, para que brilhe a força do Evangelho na vida cotidiana, familiar e social" (LG 31. Também os nn. 12 e 35). A missão profética dos leigos tem origem no próprio Cristo, que os "constituiu" como "testemunhas", deu-lhes o "senso da fé" e a "graça da palavra".

Foi Cristo mesmo quem desejou fazer de todos os seus fiéis partícipes do seu múnus profético. Para isso deu-lhes o senso da fé. Esse texto deve ser lido em sintonia com o n. 12 que afirma a participação de todo o Povo de Deus na missão profética de Cristo. Aqui, o sensus fidei tem origem na "unção do Santo" (cf 1Jo 2,20 e 27) e trata-se de uma peculiar propriedade pela qual o conjunto dos fiéis não pode enganar-se no ato de fé. Por essa virtude, o cristão batizado, ao receber a Palavra de Deus, a ela apega-se indefectivelmente, compreende-a em profundidade e aplica-a em sua vida. E mesmo que tal vivência aconteça sob a direção do magistério da Igreja, afirma uma capacidade nos leigos de conservarem infalivelmente a Palavra. Tal deve-se à ação do Espírito Santo, mais do que ao ensinamento do magistério.

O sensus fidei e a "graça da palavra" estão intimamente ligados no exercício do múnus profético. A graça de Cristo instrui os fiéis na palavra, para que ela seja proclamada profeticamente, "quer agrade, quer desagrade"... Trata-se da palavra do Evangelho, que move o coração dos ouvintes para acolherem a proposta do Reino. Sendo a missão de proclamar a palavra também dos leigos, é fundamental que eles "procurem um conhecimento mais profundo da verdade revelada e instantemente peçam a Deus o dom da sabedoria" (LG 35). E a "graça da palavra" que faz com que a força do Evangelho brilhe na vida cotidiana, familiar e social (LG 35), testemunho fundamental na evangelização. Assim, a fé em Cristo é difundida "tanto por palavras como por obras" (LG 11).

A dimensão profética é vivida pelos leigos não apenas pela proclamação da palavra, mas também pelos carismas que o Espírito Santo distribui no meio do Povo de Deus. O Espírito Santo, "repartindo seus dons 'a cada um como lhe apraz' (1Cor 12,11), distribui também entre os fiéis de qualquer ordem graças especiais. Por elas os torna aptos e prontos a tomarem sobre si os vários trabalhos e ofícios que contribuem para a renovação e o maior incremento da Igreja, segundo estas palavras: 'A cada um é dada a manifestação do Espírito para a utilidade comum' (1Cor 12,7)” (LG 12). O Espírito atua, portanto, através dos sacramentos, dos ministérios, da palavra e dos carismas. Paulo fala de uma variedade de carismas, dons e serviços, que edificam a comunidade de 
fé (Rm 12 e 1Cor 12). Claro, faz-se necessário discernimento apurado para compreender e acolher os dons e carismas do Espírito de modo a contribuir eficazmente na evangelização. Não se trata de esperar coisas espetaculares, e nem de esperar presunçosamente dons extraordinários. E aqui também não há espaço para o individualismo. Todo carisma, todo dom, é em vista de uma missão, um serviço na comunidade cristã e no mundo.

Outras passagens significativas da Lumen Gentium que enfatizam a dimensão profética do ministério leigo:

- Por toda parte dêem testemunho de Cristo. E aos que pedirem dêem razões de sua esperança (LG 10);

- Devem dar o testemunho de uma vida santa (LG 10);

- Pelo batismo são obrigados a professar diante dos homens a fé que receberam de Deus pela Igreja (LG 11);

- Pela confirmação são de modo especial enriquecidos com a força do Espírito Santo e assim mais estreitamente obrigados à fé que, como verdadeiras testemunhas de Cristo, devem difundir e defender por palavras e obras (LG 11);

- Manifestem Cristo aos outros, especialmente pelo testemunho de sua vida resplandecente em fé, esperança e caridade (LG 30);

- Todo leigo é ao mesmo tempo testemunha e instrumento vivo da missão da própria Igreja (LG 33);

- Os leigos se apresentam como filhos da promessa quando, fortes na fé e esperança, aproveitam o momento presente e esperam a glória futura pela paciência. E não escondam esta esperança no íntimo da alma, mas, pela renovação contínua e pela luta contra os dominadores do mundo das trevas, contra os espíritos da malícia, exprimam-na nas estruturas da vida secular (LG 35);

- Com a vida da fé conjuguem intrepidamente a profissão da fé. Esta evangelização, isto é, este anunciar de Cristo por um testemunho vivo e pela palavra falada, adquire características específicas e eficácia particular pelo fato de se realizar nas condições comuns do século (LG 35).

Numa análise geral destes textos, vemos que o apostolado profético dos leigos realiza-se no mundo atual onde os leigos são chamados a mostrarem as razões da sua esperança (LG 10), não de modo intimista e tímido, mas em público, nas estruturas da vida secular (LG 35). Esse apostolado fundamenta-se nas verdades teologais da fé, esperança e 
caridade, e inclui a vida familiar, onde os "cônjuges têm uma vocação própria, para que sejam mutuamente e para os filhos testemunhas da fé e do amor de Cristo" (LG 35).

c) Régio: Cristo é o único Rei, Senhor e "Cabeça do novo e universal Povo dos filhos de Deus" (LG 13) e na sua realeza foram inseridos todos os cristãos batizados. Por essa razão, os batizados participam do múnus régio de Cristo (LG 31 e sobretudo 36), de modo que participam da missão de fazer acontecer o Reino de Cristo na terra. Ele quer construir "também através dos fiéis leigos seu Reino, reino de verdade e vida, reino de santidade e graça, reino de justiça, amor e paz" (LG 36). Isso exige reconhecer que tudo em Cristo foi criado e tudo a ele se ordena. Daqui, o apostolado específico do leigo, visto acima: animar e informar com o espírito cristão a mente e os costumes, as leis e as instituições sociais ou comunitárias. ${ }^{28}$ Isso inclui a vida toda e seus bens, como também a família, a cultura, a economia, a arte, as profissões, a política, (AA 7). Claro, tal fato não equivale a negar a autonomia da ordem temporal. Trata-se, antes, de compreender que na medida em que ela contribui para a realização do ser humano, diz respeito também a Deus, o qual dá transcendência a esse mundo, em Cristo Jesus, "para que Ele seja em tudo o primeiro" (Col 1,18). O grande compromisso de "ordenar as coisas segundo Deus" consiste em transformar as realidades terrestres que não condizem com o Evangelho. É fazer com que "o mundo seja imbuído do espírito de Cristo e na justiça, caridade e paz atinja mais eficazmente seu fim" (LG 36).

E nisso "compete aos leigos a principal responsabilidade" (LG 36) de sanar as instituições e condições do mundo, de modo que favoreçam a realização do desígnio de Deus na terra. Daqui a importância de os leigos manterem uma justa distinção e ao mesmo tempo uma equilibrada relação entre a pertença à Igreja e à Sociedade, simultaneamente. Atuando no mundo, “devem ser conduzidos pela consciência cristã" (LG 36).

\section{Em tempos do papa Francisco}

Em sua exortação apostólica Evangelii gaudium, o papa Francisco faz uma real análise da ação do leigo na Igreja e no mundo em nossos dias. Diz no n. 102:

${ }^{28}$ KLOPPENBURG, B. A Eclesiologia do Vaticano II, p. 251. 
A imensa maioria do povo de Deus é constituída por leigos. Ao seu serviço, está uma minoria: os ministros ordenados. Cresceu a consciência da identidade e da missão dos leigos na Igreja. Embora não suficiente, pode-se contar com um numeroso laicato, dotado de um arraigado sentido de comunidade e uma grande fidelidade ao compromisso da caridade, da catequese, da celebração da fé. Mas a tomada de consciência desta responsabilidade laical que nasce do Batismo e da Confirmação não se manifesta de igual modo em toda a parte; nalguns casos, porque não se formaram para assumir responsabilidades importantes, noutros por não encontrar espaço nas suas Igrejas particulares para poderem exprimir-se e agir por causa dum excessivo clericalismo que os mantém à margem das decisões. Apesar de se notar uma maior participação de muitos nos ministérios laicais, este compromisso não se reflete na penetração dos valores cristãos no mundo social, político e econômico; limita-se muitas vezes às tarefas no seio da Igreja, sem um empenho real pela aplicação do Evangelho na transformação da sociedade. A formação dos leigos e a evangelização das categorias profissionais e intelectuais constituem um importante desafio pastoral.

Observamos aqui o reconhecimento de que os leigos, maioria na Igreja, crescem em consciência eclesial e na prática de uma fecunda evangelização. De fato, após o concílio surgiram nas Igrejas locais os conselhos nos quais os leigos participam mais ativamente nas discussões, planejamentos e execução de tarefas na vida cotidiana da Igreja; desenvolvem importantes funções nas celebrações litúrgicas; administram (ainda que de forma extraordinária) o sacramento do Batismo e do Matrimônio; colaboram na administração dos bens materiais da comunidade; muitos formam e coordenam comunidades com base em uma espiritualidade ou carisma e missão próprios; constituem um jeito próprio de ser nas Comunidades Eclesiais de Base. Isso expressa crescente fidelidade ao Evangelho, que sustenta a responsabilidade batismal. De fato,

Cada um dos batizados, independentemente da própria função na Igreja e do grau de instrução da sua fé, é um sujeito ativo de evangelização, e seria inapropriado pensar num esquema de evangelização realizado por agentes qualificados enquanto o resto do povo fiel seria apenas receptor das suas ações" (EG 120). 
Mas o número 102 da Evangelii gaudium mostra também que essa não é uma realidade em todos os ambientes e instâncias eclesiais. Com realismo, o papa Francisco pode dizer que também na implantação do concílio "os frutos são escassos e as mudanças são lentas” (EG 277). Constata, dentre as dificuldades, a falta de formação e o clericalismo, que não dá espaço para o leigo atuar com liberdade na Igreja. Além disso, existe o desafio em fazer com que o testemunho da fé aconteça também no meio social, e não apenas no interior da Igreja, transformando a sociedade conforme os critérios do Evangelho. Frente a isso, o papa da "teologia do povo" 29 insiste que "A nova evangelização deve implicar um novo protagonismo de cada um dos batizados" (EG 120), pois em todos "atua a força santificadora do Espírito que impele a evangelizar" (EG 119). Precisamos "crescer como evangelizadores" (EG 121), através da formação e do "aprofundamento do amor". Fundamental é o espírito de companheirismo e corresponsabilidade, que permite entender que "todos devemos deixar que os outros nos evangelizem constantemente" (EG 121). Vemos aqui perfeita coerência do magistério do papa argentino com o Vaticano II. E na esteira desse concílio o pontificado de Francisco se propõe a fazer uma "renovação eclesial inadiável" (EG 27), capaz de reformar as "estruturas centrais" da Igreja (EG 32), como a cúria romana e o próprio papado, no horizonte de uma "pastoral em conversão" (EG 25) que caracterize uma "Igreja em saída missionária" (EG 17). É nesse projeto eclesial que o leigo tem assegurado o seu lugar e a sua função de protagonista no testemunho do Evangelho em nossos dias.

\section{Concluindo: leigas e leigos nas estruturas eclesiásticas?}

Como vimos, as leigas e os leigos formam a Igreja Povo de Deus, na comum dignidade sacramental do Batismo cristão. Participam do tríplice múnus de Cristo e desenvolvem importantes funções no interior da comunidade de fé e na missão da Igreja no mundo. Mas não lhes é facultado nenhum espaço efetivo nas estruturas eclesiásticas. E a condição da mulher é duplamente fragilizada na Igreja: por ser leiga e por ser mulher em espaços onde ainda vigora uma cultura patriarcal e sexista.

O que justifica isso? Por quê a corresponsabilidade da missão não se

\footnotetext{
${ }^{29}$ SCANNONE, J. C. “A 'teologia do povo' do papa Francisco”. Disponível em: <https:// berakash.blogspot.com.br/2013/09/a-teologia-do-povo-do-papa-francisco.html>. Acesso em 28 de janeiro de 2018.
} 
estende também ao governo eclesial numa real interação e complementariedade que supere de vez a prática de subordinação na relação entre o clero e leigas e leigos? Se reconhecemos uma imprescindível contribuição das mulheres na sociedade e também na Igreja, pela ação pastoral e a reflexão teológica, como garantir a sua presença "nos vários lugares onde se tomam as decisões importantes" na Igreja, tal como a queremos na sociedade (EG 103)? São questões que emergem do estado atual de como as leigas e os leigos vivem sua condição cristã. $\mathrm{O}$ fato é que, afirmar de forma consequente a "dignidade da mulher" ${ }^{\prime 0}$ de modo a integrá-la definitivamente na totalidade da vida eclesial, deve levar pastores e teólogas/os a enfrentem responsavelmente o desafio de "ajudar a reconhecer melhor o que isto implica no que se refere ao possível lugar das mulheres onde se tomam decisões importantes, nos diferentes âmbitos da Igreja" (EG 104). O papa Francisco está convicto de que "na crise cultural do nosso tempo, a mulher encontra-se na linha de vanguarda na batalha pela salvaguarda do humano". ${ }^{31}$ Mas para reconhecer a mulher como vanguarda no cuidado também das estruturas eclesiais, o caminho é ainda longo.

Porém, estamos no caminho. A partir do Vaticano II, o papel das leigas e dos leigos foi assumido pastoralmente. Em muitas dioceses e paróquias foram criados os conselhos de pastoral e os conselhos de leigas/leigos, de modo a lhes possibilitar melhor participação nos processos de evangelização. Alguns desses conselhos, infelizmente poucos, funcionam exemplarmente, pelos quais a comunidade é integrada nas discussões e nas decisões dos projetos de missão. Observa-se, assim, o ensino conciliar de que leigas e leigos têm o direito e até mesmo o dever de exprimir sua opinião sobre elementos que dizem respeito à Igreja:

Os sagrados pastores reconheçam e promovam a dignidade e a responsabilidade dos leigos na Igreja. De boa vontade utilizem seu prudente conselho. Com confiança entreguem-lhes ofícios no serviço da Igreja. E deixem-lhes liberdade e raio de ação. Encorajem-nos até para empreender outras obras por iniciativa própria. Com amor paterno considerem atentamente em Cristo as iniciativas, os votos e os desejos

\footnotetext{
30 JOÃO PAULO II. "Mulieris Dignitatem" (1988). Disponível em: < http://w2.vatican.va/ content/john-paul-ii/pt/apost_letters/1988/documents/hf_jp-ii_apl_19880815_mulieris-dignitatem.html $>$. Acesso em 20 de janeiro de 2018.

${ }^{31}$ FRANCISCO. "Discurso à plenária do Pontifício Conselho para os Leigos" (07/12/2013). Disponível em: <http:/w2.vatican.va/content/francesco/pt/speeches/2013/december/documents/papa-francesco_20131207_plenaria-laici.html>. Acesso em 10 de janeiro de 2018.
} 
propostos pelos leigos. Respeitosamente reconheçam os Pastores a justa liberdade que a todos compete na cidade terrestre (LG 37). ${ }^{32}$

O concílio dá voz aos leigos e às leigas na Igreja e orienta, quase em tom de receio de tal liberdade, que o falar aconteça com amor à verdade, com coragem, com prudência, com reverência e com caridade (LG 37). Naturalmente justo, mas o mesmo espera-se também do ministro ordenado. Fundamental é que a Igreja não tenha medo de um "laicato adulto", ${ }^{33}$ que seja mais protagonista do que colaborador da hierarquia, indicando um novo jeito de exercer a autoridade na Igreja. Uma Igreja aberta para a ministerialidade a partir do Batismo comum, sem manipulação ou indevida submissão. Em nossos tempos, o papa Francisco pergunta: "Tanto estes (Conselhos Diocesanos) como os Conselhos paroquiais de Pastoral e de Assuntos Econômicos são espaços reais para a participação laical na consulta, organização e planejamento pastoral?". Pergunta crucial para os tempos de concentração clerical da vida da Igreja. E o papa constata, com pesar: "Acho que estamos muito atrasados nisso". ${ }^{34}$ A questão, voltamos, é como a atuação leiga pode acontecer também no múnus de regência. A participação das leigas e dos leigos nas estruturas de governo na Igreja é uma das últimas fronteiras a ser transpostas para uma efetiva e eficaz vivência da comunhão na Igreja. Não se trata de fazer da Igreja uma república ou uma sociedade democrática, simplesmente. E é mais que uma questão de poder. É uma convicção evangélica de que na comunidade cristã o que deve ser assumido por todos, deve ser também decidido por todos. E certamente "desta convivência familiar entre Leigos e Pastores se esperam muitos bens para a Igreja" (LG 37).

Em especial para a Igreja no Brasil, espera-se que a retomada da teologia do laicato no horizonte conciliar fortaleça a missão da Igreja no meio social.

${ }^{32}$ E no n. 9 de PO, o Concílio pede aos presbíteros que "reconheçam e promovam sinceramente a dignidade dos leigos e suas incumbências na missão da Igreja. Acatem conscienciosamente a justa liberdade que é quinhão de todos na cidade terrestre. Ouçam com gosto os leigos, apreciando fraternalmente os seus desejos, reconhecendo sua experiência e competência nos campos da atividade humana, para poderem junto com eles verificar os sinais dos tempos... Entreguem com confiança tarefa aos leigos para o serviço da Igreja, deixando-lhes liberdade e possibilidade de agir, convidando-os mesmo oportunamente a enfrentar obras também por sua iniciativa".

${ }^{33}$ SCOPINHO, S. C. D. Igreja e Laicato Adulto. São Paulo: Paco Editorial, 2012.

${ }^{34}$ FRANCISCO. "Textos do Papa Francisco na sai viagem apostólica ao Brasil, por ocasião da XXVIII Jornada Mundial da Juventude (22 a 28 de julho de 2013) - Encontro com os dirigentes do CELAM". Acesso em 22 de janeiro de 2018. 
Pois "para que as comunidades (e paróquias) possam ser bem servidas e crescer na fé, é necessário estimular a participação de leigos nos diferentes ministérios e serviços". ${ }^{35}$ Para isso, muito contribui o Ano do Laicato (2018), o qual

não pode ser somente mais uma celebração, ainda que a condição cristã deva ser comemorada a todo momento. Deverá ser um momento de conversão da Igreja; de saída de si mesma na busca de suas fontes (do coração do Evangelho) e na direção do outro (de modo especial dos pobres e dos sofredores). Deverá ser o ano da conversão para o laicato, condição comum de todos os batizados; conversão para o serviço de todos a todo o povo de Deus e de serviço do povo de Deus a todos os povos que habitam o planeta com suas diferenças, anseios e esperanças. ${ }^{36}$

\section{Referências bibliográficas}

BÍBLIA. Tradução Ecumênica da Bíblia (TEB). São Paulo: Loyola, 1994.

BLANK, R. Ovelha ou Protagonista? A Igreja e a nova autonomia do laicato no século 21. São Paulo: Paulus, 2006.

CNBB. Comunidade de comunidades: uma nova paróquia. A conversão pastoral da paróquia. Documentos da CNBB n. 100. Brasília: Edições CNBB, 2014.

CNBB. Cristãos Leigos e Leigas na Igreja e na Sociedade - Sal da terra e luz do mundo. Documento de Estudos n. 105. Brasília: Edições da CNBB, 2016.

CONCÍLIO VATICANO II. “Apostolicam Actuositatem”. In: DOCUMENTOS DO CONCÍLIO VATICANO II. São Paulo: Paulus, 2007, pp. 369-408.

CONCÍLIO VATICANO II. "Gaudium et Spes". In: DOCUMENTOS DO CONCÍLIO VATICANO II. São Paulo: Paulus, 2007, pp. 539-558.

CONCÍLIO VATICANO II. "Lumen Gentium". In: DOCUMENTOS DO CONCÍLIO VATICANO II. São Paulo: Paulus, 2007, pp. 101-192.

${ }^{35}$ CNBB. Comunidade de comunidades: uma nova paróquia. A conversão pastoral da paróquia. Documentos da CNBB n. 100. Brasília: Edições CNBB, 2014, n. 307.

36 GRUPO DE REFLEXÃO DA COMISSÃO EPISCOPAL DE PASTORAL PARA O LAICATO DA CNBB. Sujeitos Eclesiais - Sal da Terra e Luz do Mundo. Reflexões sobre o documento 105. São Paulo: Paulinas, 2018, p. 12. 
CONCÍLIO VATICANO II. "Presbiterorum Ordinis". In: DOCUMENTOS DO CONCÍLIO VATICANO II. São Paulo: Paulus, 2007, pp. 491-536.

FORTE, B. A Missão dos Leigos. São Paulo: Paulinas, 1987.

FRANCISCO. Evangelii Gaudium. São Paulo: Paulus/Loyola, 2013.

FRANCISCO. "Discurso à plenária do Pontifício Conselho para os Leigos" (07/12/2013). Disponível em: <http://w2.vatican.va/content/francesco/ pt/speeches/2013/december/documents/papa-francesco_20131207_ plenaria-laici.html $>$. Acesso em 10 de janeiro de 2018.

FRANCISCO. "Discurso aos participantes da assembleia do Pontifício Conselho para os Leigos" (jun. 2016). Disponível em: <http://blogs. opovo.com.br/ancoradouro/2016/06/17/precisamos-de-leigos-comvisao-do-futuro-diz-papa-francisco/>. Acesso em 15 de janeiro de 2018.

FRANCISCO. "Discurso do papa Francisco aos membros da associação 'corallo' que reúne as emissoras televisivas católicas italianas" (22/03/2014). Disponível em: <https://w2.vatican.va/content/francesco/ $\mathrm{pt} /$ speeches/2014/march/documents/papa-francesco_20140322_ associazione-corallo.html $>$. Acesso em 15 de janeiro de 2018.

FRANCISCO. "Encontro com os líderes do apostolado leigo" (República da Coreia, VI Jornada da Juventude Asiática, República da Coreia, 16/08/2014). Disponível em: <http://w2.vatican.va/content/francesco/ pt/speeches/2014/august/documents/papa-francesco_20140816_corealeader-apostolato-laico.html>. Acesso em 28 de janeiro de 2018.

FRANCISCO. "Mensagem de vídeo do papa Francisco aos participantes no encontro de políticos católicos organizado pelo Conselho Episcopal Latino-americano e pela Pontifícia Comissão para a América Aatina (cal)" (Bogotá 1 - 3/12/2017). Disponível em: <http://w2.vatican.va/ content/francesco/pt/messages/pont-messages/2017/documents/papafrancesco_20171201_videomessaggio-cattolici-inpolitica.html $>$. Acesso em 10 de dezembro de 2017.

FRANCISCO. "Homilia na missa na casa Santa Marta" (31/10/2017). Disponível em: <http://pt.radiovaticana.va/news/2017/10/31/papa para_fazer_crescer_o_reino_de_deus_precisa-se_coragem $/ 1346200>$. Acesso em 22 de dezembro de 2018. 
FRANCISCO. "Textos do Papa Francisco na sua viagem apostólica ao Brasil, por ocasião da XXVIII Jornada Mundial da Juventude (22 a 28 de julho de 2013) - Encontro com os dirigentes do CELAM". Disponível em: $<$ www.diocesedejales.org.br/home/discursos-e-homilias-do-papafrancisco-na-jmj-rio-2013/>. Acesso em 22 de janeiro de 2018.

GRUPO DE REFLEXÃO DA COMISSÃO EPISCOPAL DE PASTORAL PARA O LAICATO DA CNBB. Sujeitos Eclesiais - Sal da Terra e Luz do Mundo. Reflexões sobre o documento 105. São Paulo: Paulinas, 2018.

JOÃO PAULO II. "Mulieris Dignitatem" (1988). Disponível em: <http:// w2.vatican.va/content/john-paul-ii/pt/apost_letters/1988/documents/hf_jp-ii_ apl_19880815_mulieris-dignitatem.html $>$. Acesso em 20 de janeiro de 2018.

KLOPPENBURG, B. A Eclesiologia do Vaticano II. Petrópolis: Vozes, 1971.

KUZMA, C. Leigos e Leigas. Força e esperança da Igreja no mundo. São Paulo: Paulus, 2009.

PASSOS, J. D. Sujeito no Mundo e na Igreja. Reflexões sobre o laicato a partir do concílio Vaticano II. São Paulo: Paulinas, 2014.

ROXO, R. M. O Concílio. Petrópolis: Vozes, 1967.

SCANNONE, J. C. “A 'teologia do povo' do papa Francisco”. Disponível em: <https://berakash.blogspot.com.br/2013/09/a-teologia-do-povo-dopapa-francisco.html>. Acesso em 28 de janeiro de 2018.

SCOPINHO, S. C. D. Igreja e Laicato Adulto. São Paulo: Paco Editorial, 2012.

Elias Wolff

Doutor em Teologia pela Pontificia Università Gregoriana (Roma) Membro do Programa de Pós-Graduação em Teologia da Pontifícia Universidade Católica do Paraná Bolsista CNPq Curitiba / PR - Brasil E-mail: elias.wolff@pucpr.br

Recebido em: 09/02/18

Aprovado em: 09/03/18 